\title{
A Theological Analysis of Issues Arising from the Christian Asante Chief's Relationship with the Black Stool (Akonwa Tuntum)
}

\begin{abstract}
One of several issues of contention that have created a gulf between Christianity and the traditional Asante chieftaincy institution is the chief's relationship with the black stool. The general perception of Christians is that the black stool is an object of worship, it is demonic and should be avoided by Christian chiefs. This paper theologically analyzes the issues of contention in the Christian chief's relationship with the black stool and presents a Christian response to guide them. This is an empirical qualitative study, and it uses a phenomenological approach to understand the phenomena related to the issues of contention in the Christianitychieftaincy encounter. The method of obtaining information included interviews of fifty (50) Christian Asante chiefs, a representative group obtained by the purposeful sampling method. Information was also obtained through personal observation of some of the traditional religious rituals they perform. The issues of contention were then examined in the light of scripture in order to help bridge the seeming gulf between Asante chieftaincy and Christianity. This research has established the fact that the black stool is not a demonic object. In fact, the issues of contention in the Christianity and chieftaincy encounter, relating to the black stool, have arisen not only from a lack of understanding and proper appreciation of the traditional rituals, but also from lack of proper understanding and poor interpretation of scriptural texts used in relating the gospel to the chieftaincy institution.
\end{abstract}

Keywords: Tradition, ritual, Christianity, Black stool (Akonwa Tuntum), worship.

\section{INTRODUCTION}

The observation of Busia that Christian chiefs of his time performed traditional religious functions still holds today among Christian Asante chiefs. He observed that:

No one could be an adequate chief who did not perform the ritual functions of his office. There have recently been elected as chiefs in different parts of the Ashanti men who are both literate and Christian. But they have all felt an obligation to perform the ritual acts of their office. They were enstooled in the stool house, where they poured libations to the ancestors whom they had succeeded ...It is as successors of the ancestors that they are venerated and their authority respected, and they could not keep the office without maintaining contact with the ancestors through the traditional rituals. ${ }^{2}$

One of the major issues that have disturbed Christian chiefs over the years has been whether they should relate to the black stool (Akonwa tuntum).

\footnotetext{
K. A. Busia, The position of the chief in the modern political system of Ashanti: A study of the influence of contemporary social changes on Ashanti political institutions (London: Oxford University Press, 1951), 38.
} 
Since theology is 'the quest for, and formulation of Christian responses to culturally rooted questions' ${ }^{3}$, this presentation attempts an examination of the issues that Christian Asante chiefs have with the black stool, from Christian theological and biblical perspectives, with the aim of formulating a Christian response to the issue of Christian Asante chief's relationship with this traditional politico-religious object.

According to Oseadeeyo Addo Dankwa, the 'Black Stool is the most important object in the palace. ${ }^{9}$ Therefore, no one can be an Akan chief without relating to this important symbol. In fact, the Asante chief is someone who has been put on an akonwa tuntum, and such a person is said to have been 'enstooled'. The akonwa tuntum is therefore of great political significance. The legitimacy and political authority of a chief is rooted in it. Among the Asante, the akonwa tuntum, as symbol of political authority is jealously guarded and protected and always kept out of public view. ${ }^{5}$

The akonwa tuntum, however, also has enormous religious significance. The Asante believe that it is enshrined by the spirits of the ancestors. ${ }^{6}$ After the death of a chief, his stool may be blackened and this ritual of blackening, ensures that his spirit enshrines the stool and can then be contacted for help and other benefits or blessings for the group..$^{7}$ It is usually the stool on which he sat to bath, or the one on which his corpse was placed and bathed before being laid in state, which was blackened. ${ }^{8}$ This is preferred, because of the belief that the bathing on it ensures that the soul of the deceased fully penetrates the stool. To have one's stool blackened, a chief should have proved to be a good leader and died a ruler. He should have died a 'good death', that is, death resulting from natural causes and not through accidents and diseases such as epilepsy, leprosy, lunacy and so on. He must have died in battle or war while not running away from the enemy. ${ }^{9}$ Moreover, he must not have committed suicide or been killed by obosom ${ }^{10}$ which resulted from witchcraft accusation. All these are to ensure that such mishaps are not repeated in the society. In addition, he should have led an exemplary life or clean life. The Asante believe that 'a bad person will not have a good ghost and it is the good ghost who blesses his children'. ${ }^{11}$ The Asante call a good ghost, osaman pa.

The mixture for blackening the stool is made of soot (which is formed in the traditional kitchen from spiders' web and smoke) mixed with raw egg. This mixture is used to smear the stool thoroughly until it becomes black. A sheep is slaughtered and the blood sprinkled on it. The mutton is shared among the court officials and the fat collected and put on the stool, after which libation is poured and prayers said to the chief whose spirit is believed to have inhabited the stool.

It is the Christian chief's relationship with these ancestral blackened stools that constitute a major source of dilemma for them. This is because the stool, having gone through the rituals of the blackening process becomes a religious object, believed to have powers of its own as it is enshrined by the spirit of the dead chief. The chief elect, on his enstoolment, is brought before the akonwa tuntum and made to sit on it. The Nkonwasoafohene (the chief in charge of the stool carriers) and the Queenmother are prominent in the enstoolment process. With the support of the Nkonwasoafohene and the Queenmother holding the chief's waist, he is lowered for his buttocks to touch the stool three times. In the process, one of the stool carriers passes his hand in between the chief's legs, to ensure that his genital organs are prevented from touching the stool, because of the belief that the powers in it could render the chief sexually impotent.

Christian chiefs who go through this enstoolment process face a serious dilemma which leads some of them to even question their status as true and authentic Christians. An Asante chief said:

As a Christian, I know the Holy Spirit dwells in me. And I also know that a certain spirit dwells in the stool. As I sat on the stool, my fear was that a strange spirit has indwelt me which is not the Spirit of

God. The thought of this has haunted me since I became a chief. ${ }^{12}$

The root of this dilemma rests on the fact that when a person sits on the stool, they believe that his nature is sacralized. He assumes a sacred nature and therefore his life is governed by taboos including the following:

i. He should not be struck by anybody;

ii. He should not strike anybody;

\footnotetext{
3 Kwame Bediako, Theology and Identity: The Impact of Culture upon Christian Thought in the Second Century and in Modern Africa (Paternoster: Regnum Books, 1992), 7.

4 Oseadeeyo Addo Dankwa III, The Institution of Chieftaincy in Ghana - The Future (Accra: Konrad Adenauer Foundation, 2004$), 67$.

5 Kwame Amoah Labi, 'Cross-cultural appropriation of regalia and royal art, and contemporary adaptations in Ghana' in Irene K. Odotei and Albert K. Awedoba, Chieftaincy in Ghana: Culture, Governance and Development (Accra: Sub-Saharan Publishers, 2006), 282

6 Peter Sarpong, The Sacred Stools of the Akan, (Tema: Ghana Publishing Corporation, 1971), 39.

Ibid.

Ibid.

Ibid, 40 .

10 Obosom is 'tutelary or guardian spirit of a town or family, imaginary spirits, subordinate to God'. This definition is taken from J. G. Christaller, Dictionary of the Asante and Fante Language called Tshi (Twi) (Basel: The Basel Evangelical Missionary Society, 1933 ), 43.

11 Sarpong, The Sacred Stools of the Akan, 40.

12 Interview with a chief on $18^{\text {th }}$ August, 2014, at the Manhyia Palace.
} 
iii. He should not walk barefooted;

iv. He must not stumble;

v. His buttocks should not touch the ground..$^{13}$

All these taboos demonstrate that the chief is no longer an ordinary person but has acquired a sacred or divine nature. The chief assumes this nature to be able to serve as the mediator between the living and the dead members of the community and the legitimacy of the authority of the Asante chief depends on the fact that he sits on the stool of the ancestors and has become, more or less, one of them. Thus, he assumes a mystical relationship with the ancestors. Boadi presents the dilemma of the Christian chief with regard to the black stools when he asserts:

In the first place, the Black Stool on which he symbolically sits is an idol. On sacred days he has to pour libation of alcoholic drinks on it and offer sacrifices to the divinities and the ancestors. Since these acts of worship are pagan, it would be wrong for a Christian chief to thus betray his faith in God. On the other hand, if he refuses to do them it will lead to his destoolment. This is a real dilemma in Africa because the Bible teaches that a Christian should worship only God (Exodus 20:4, 5). ${ }^{14}$

This statement and response of some of the Asante Christians chiefs pose serious questions that have to be responded to, in order to enable them function both as chiefs and Christians without any dilemma. They include the following:

i. The perception that the akonwa tuntum is demonic.

ii. The fear that the Christian chief is spiritually contaminated by sitting on akonwa tuntum.

iii. The perception that the akonwa tuntum is worshipped.

These are the issues that have to be examined from theological and biblical perspectives to help in the formulation of a Christian response to the Christian Asante chief's relationship with the Akonwa tuntum.

\section{Analysis of the issues arising from the akonwa tuntum}

The akonwa tuntum, the most important object in the chieftaincy institution, is also the most misunderstood and condemned in Christian circles because the stools are kept out of public view and rituals associated with them are kept in secrecy. Some Christians perceive them to be demonic, others see them as deities that are worshipped, and to others the Christian chiefs who sit on them become spiritually contaminated. These issues have been the source of dilemma of Christian chiefs as they relate to this object of the chieftaincy institution and therefore a theological response to them will enable them to be able to interpret their religious functions and rituals in the light of the Gospel that they have embraced. This will ensure that Christian chiefs perform their functions as traditional rulers and hold on to the Christian faith without the inner conflicts they go through as they perform the rituals associated with the Akonwa tuntum.

\section{The perception that the akonwa tuntum is demonic}

The first issue that disturbs Christian chiefs with regards to the akonwa tuntum is the perception that the akonwa tuntum is an object of worship and is also believed to be enshrined by the spirits of Nananom Nsamanfor (ancestors), which are demonic spirits and not God's Spirit. To effectively deal with this issue, there is the need to know what the akonwa tuntum is, the reason for its institution, and the functions that it serves in the social, religious, political, and cultural lives of the Asante people.

What is the akonwa tuntum and why was it instituted? At the death of a good chief ${ }^{15}$ the elders of the village or community, in collaboration with the new chief, decide to 'blacken' his stool. The Asante say 'Yع punu n'akonwa' which means 'we are going to blacken his stool'. As mentioned earlier, the stool on which he sat to bath or the one on which his corpse was bathed before burial was the preferred one. It goes through the ritual processes of blackening to ensure that it is preserved from decaying. Primarily, therefore, the blackening of the stool is to memorialize the name and reign of the chief. ${ }^{16}$ Such a chief and his good deeds will always be remembered as his name and deeds are recounted at every 'Adae' festival. The greatest honour the people can give to their departed chief is to 'blacken' his stool. It stands for the acknowledgment and recognition of the good deeds that the chief performed for his community and it is done for the chief who earned the respect of his subjects. Addo Dankwa III sums up the qualifications by which a chief earns the respect of the subjects when he states thus:

In fact, as an active participant in the chieftaincy drama, I can testify to the fact that a chief can earn the respect of his subjects not because he is a sacred person who maintains strict adherence to the tenets of the rituals, but on the basis of his righteousness, comportment and meaningful contribution to the

\footnotetext{
13 Busia, The Position of the Chief, 26-27.

14 J.A. Boadi, Christianity or Traditional Beliefs and Customs? (Accra: U.G.C. Publishing House, 2001), 104.

15 A good chief should have led an exemplary life or clean life, and should have died a good death, that is, death resulting from natural causes and not through accidents and diseases such as epilepsy, leprosy, lunacy etc. He must have died in battle or war while not running away from the enemy (having the injury in front of him and not at his back).

16 Addo Dankwa, The Institution of Chieftaincy in Ghana, 73.
} 
well-being of his people. ${ }^{17}$

In traditional Asante society which was mainly non-literate, historical events and information were preserved in the form of sculptural items such as the akonwa tuntum and stories behind them were transmitted orally from generation to generation. Therefore, at every Akwasidae ${ }^{18}$ festival when the chief and elders enter the nkonwadanmu (stool room), the court historians narrate the name and the deeds of the chiefs whose memories have been preserved by the nkonwa tuntum and by so doing orally recount the history of the community and the information is thus passed on from generation to generation. Addo Dankwa III therefore refers to the akonwa tuntum as the "History book of the origin of the community'. ${ }^{19}$ Opuni-Frimpong also asserts that the akonwa tuntum 'is the indigenous symbol that is used for the documentation of traditional leaders and their performance and each stool represents a chapter in the history book of the community. ${ }^{20}$

This assertion is true because when the chief goes to the nkonwadanmu for every Adae ceremony, the court historians who are well versed in the oral history of the community recite the good deeds of each chief to his hearing and from this he is expected to take lessons which will influence his reign. Addo Dankwa, however, observes that this purely cultural ritual has been made to assume 'idol and fetish forms' and attributes this to 'improper oral transmission. ${ }^{21}$ This is an example of what Tenney describes as 'one of the basic paradoxes which plague religion. ${ }^{22}$ According to him, 'Man needs symbols as a means of expressing religious faith. Repeatedly, however, the symbols have become ends in themselves. They have lost their original purpose'. ${ }^{23}$ Repeatedly over the years therefore people have tended to regard the akonwa tuntum as an object of worship. The Christian chief can therefore approach the akonwa tuntum as a purely cultural symbol.

The akonwa tuntum also serves to achieve political ends. First, it represents the symbol of authority of the Asante. The ruling family are those in possession of the akonwa tuntum and that is the reason why it is jealously guarded. An elected chief goes to the nkonwadanmu and assumes possession of the nkonwa (stools) and this authenticates or legitimizes his office. A chief's leadership will not be recognized if he does not have akonwa tuntum. The chief is the one who sits on Nananom nkonwa so (the stools of the ancestors). He refers to the stools as me nananom nkonwa, which means 'the stools of my ancestors' and he ascended the akonwa by virtue of his ability to trace his descent to a dead relative who once occupied it and whose memory is kept by the akonwa tuntum and the rituals associated with it. ${ }^{24}$ The absence of akonwa tuntum therefore indicates a lack of legitimacy to rule.

The akonwa tuntum rituals also serve to put a check on the excesses in the use of political power. Every chief knows that if he rules well, his stool will be blackened and the memory of his name and his deeds will be preserved. This is not automatic for all chiefs, it is reserved for chiefs who earn the respect of the subjects. The fear that his memory will not be preserved acts as a check or control on the abuse of political power. The greatest legacy that a chief can leave for his family is akonwa tuntum which gives them the right and legitimacy to the highest political office in the community. The desire to have one's stool blackened after his death therefore tends to control the chief to rule with the consent of the elders who also represent the various families and clans.

From all that has been discussed about the intended purposes of the akonwa tuntum, it is clear that it could be regarded as a cultural symbol whose rituals are meant for historical, educational and socio-political purposes. It is therefore not to be regarded as a demonic or devilish object.

\section{The Christian chief's fear of contamination by the akonwa tuntum}

One of the fears of Christian chiefs with regard to the akonwa tuntum is that the stool has powers which can contaminate or take possession of the chief when he sits on it during the installation ceremony. The question that has to be grappled with in dealing with this fear is whether a Christian can be contaminated by what he touches and consequently whether by sitting on the stool he can be possessed or contaminated by the powers of the stool. Two incidents in the gospels can help one handle this issue. These include: Jesus' encounter with the woman with the issue of blood in Luke 8:40-44; Mark 5:21-34 and Jesus and the healing of a leper in Matthew 8:1-4.

\footnotetext{
17 'bid, 71.

18 Akwasidae is the festival of the Asante people which is celebrated on Sunday. The Asante also have Awukudae which is celebrated on Wednesday. The two ceremonies are observed twice in every successive period of forty-three days. A period of 22 days elapses between an Akwasidae and Awukudae, and a period of 17 days between and Awukudae and the next Akwasidae.

19 Addo Dankwa, The Institution of Chieftaincy in Ghana, 73.

20 Kwabena Opuni-Frimpong, Indigenous Knowledge \& Christian Missions: Perspectives of Akan Leadership Formation on Christian Leadership Development (Accra: SonLife Press, 2012), 151.

21 Addo Dankwa, The Institution of Chieftaincy in Ghana, 77.

22 G. E. Farley, 'Circumcision' in Merrill C. Tenney (ed.), Pictorial Encyclopedia of the Bible, Volume 1: A-C, (Grand Rapids: The Zondervan Publishing House, 1976), 868.

${ }_{23}$ Farley, 'Circumcision' in Tenney (ed.), Pictorial Encyclopedia of the Bible, 868.

${ }^{24}$ Addo Dankwa. The Institution of Chieftaincy in Ghana, 67-68.
} 


\section{Jesus' encounter with the woman with the issue of blood in Luke 8:40-44; Mark 5:21-34}

In this episode, Jesus was on his way to the house of Jairus, ruler of the synagogue, to heal his daughter who was dying, and the crowds 'almost crushed him' (Lk. 8:43, NIV). Then a woman who had been suffering from the issue of blood or bleeding for twelve (12) years came from behind Jesus and touched his cloak because she had thought 'if I just touch his clothes, I will be healed' (Mk 5:28 NIV). After touching the cloak of Jesus, the bleeding stopped immediately. Such a woman was regarded as unclean and therefore forbidden from touching anybody. Leviticus 15:25-33 imposes restrictions on such a person who was thus 'shut out from fellowship and religious life. ${ }^{25}$ One can therefore appreciate the fact that the woman came forward to Jesus frightened and trembling 'not only from a sense of shame but also because the complaint involved legal impurity'. ${ }^{26}$ However, when she touched Jesus, he did not become unclean but the woman was healed and cleansed.

\section{Jesus' healing of a leper in Matthew 8: 2-4}

In the story of Jesus healing a leper, he had come down from the mountainside and was followed by a large crowd when a man suffering from leprosy came and knelt down before him and asked for healing. Jesus reached out and touched him and immediately he was cured of his leprosy. Leprosy was abhorred in Jewish society and lepers were not allowed to mingle with other members of society. To touch a leper, according to Kapolyo, was 'something that no healthy man would do to a leper. ${ }^{27}$ The Jews abhorred leprosy because the leper was considered unclean and all with whom he came into direct contact also became ceremonially unclean. ${ }^{28}$ The reason why Jesus had to reach out to touch the leper, according to Carson, was 'because the leper did not dare come close to him and that by touching an unclean person, Jesus would become ceremonially unclean. ${ }^{29}$ However, Jesus touched the leper and instead of becoming unclean, he was undefiled and the leper got cured and cleansed. Carson asserts that 'formally speaking, Jesus has already transcended the law by touching the leper without being defiled' ${ }^{30}$

From the two episodes, it is clear that Jesus has not been defiled by what he touches. This has implications for the Christian, which can be further extrapolated from Jesus' statements to a listening crowd in Matthew 15:11. He states: 'What goes into a man's mouth does not make him "unclean", but what comes out of his mouth, that is what makes him "unclean"' (Matt. 15:11, NIV). And also, in the Gospel of Mark, Jesus says: 'Nothing outside a man can make him "unclean" by going into him. Rather, it is what comes out of man that makes him "unclean"” (Mark 7:15, NIV).

The statement of principle in these two quotations which is the point of importance is the fact that "nothing outward can defile; uncleanliness comes from within. ${ }^{31}$ What defiles a Christian are the things that derive from within him, out of his heart or will, including his thoughts, desires and the consequent actions that result from these. ${ }^{32}$ Jesus recounted the evils that spring from a people's heart and that defile them to include evil thoughts, adulteries, fornications, murders, thefts, covetousness, wickedness, deceit, lasciviousness, an evil eye, blasphemy, pride, and foolishness (Mark 7: 21,22). The Asante Bible renders these evils as 'adwemmone, adwamansem, akoronosem, awudisem, ayerfasem, anibereberee, amumuye, nsisie, ahohwie, ani bone, abususem, ahantan ne nkwaseasem.' In Asante tradition, some of these issues can lead to the destoolment of a chief, because a chief who engages in them is not fit to occupy a stool. The chief is thus defiled. Therefore, a claim can be made that a Christian chief cannot be contaminated or defiled by external contact with nor by sitting on the akonwa tuntum. That cannot 'render a man unfit for communion with God and should not bring a stain upon the conscience ${ }^{33}$ but rather what goes on in the chief which manifests in his behaviour and how he acts towards his people defiles him as the words of Jesus in Mark 7 affirm.

\section{The perception that the akonwa tuntum is worshipped}

Another issue that underlies the dilemma of the Christian chief that has arisen out of the akonwa tuntum rituals is the perception that the black stool is worshipped. Addo Dankwa III attempts an answer to this question when he asserts:

What has happened was that these aspects of the culture of the ancestors, like the Black Stools which were at first intended to act as preservatives and historical documents gradually, as a result of improper oral transmission took on idol and fetish forms which, surreptitiously, transformed those cultural rituals resulting in most cases, the purely cultural acts assuming mystical importance at the expense of their

\footnotetext{
25 Darrell L. Bock, Luke: Vol. 1 (Grand Rapids: BakerBooks, 1994), 793.

26 Henry Wansbrough (ed.), The New Jerusalem Bible (London: Darton: Longman \& Todd Ltd, 1985), 1667. The writers of the various chapters of this commentary were not identified by name.

27 Joe Kapolyo, Matthew in Tokumboh Adeyemo (ed.), Africa Bible Commentary (Nairobi: WordAlive Publishers, 2006 ), 1126.

28 Carson, 'Matthew' in Gaebelein (ed.), The Expositor's Bible Commentary, 198.

9 Ibid, 199.

30 Ibid.

Walter W. Wassel, 'Mark' in Gaebelein (ed.), The Expositor's Bible Commentary, 680.

Ibid.

3 Gerald Peterman (ed.), Matthew Henry's Commentary for the NIV (London: Harper Collins Publishers, 1992), 182.
} 
essence and meaning. ${ }^{34}$

His claim, which has already been discussed, is that originally, the stools were for cultural and historical purposes. His argument, however, raises a serious methodological issue which lacks scholarly proof. The questions of when and how the institution assumed purely cultural and historical purposes has to be resolved. However, what is clear is that the application of the blood of sheep to the nkonwa tuntum during the monthly Akwasidae ceremonies is for the preservation of the stools. An Asante Christian chief explained that his ancestors migrated from Denkyira in the $18^{\text {th }}$ Century with their stools and that these original stools have been preserved to date by the monthly application of blood to them. He explained further that any time a chief stopped the application of the blood to them. He explained further that any time a chief stopped the application of the blood to the stools, they begun to show signs of decay. ${ }^{35}$ Christians, however, see the akonwa tuntum as a deity because the killing of the animal is seen as a sacrifice to a deity and the application of the blood as a form of worship of the deity. Addo Dankwa III vehemently argues that the akonwa tuntum is not a deity when he asserts that:

If a Black Stool is a deity, is it then a special deity different from the other known deities (Abosom), which have mediums and fetish priests, since in the case of the real deity, if it wants to communicate to its adherents, enters into the medium who is possessed and speaks a strange language to be interpreted by the fetish linguist. It is through this that the intentions of the deity are made known to the adherents. In the Akan Chief's court, there are no mediums and fetish linguists who speak strange languages to be interpreted by the linguists to reveal to the people the intentions of the so-called divine stool or ancestors. ${ }^{36}$

From Addo Dankwa's assertion, one can argue that the akonwa tuntum is not worshipped and that when the Christian chief applies blood to the stool during Akwasidae he is not worshipping a deity or idol but rather preserving his stools. In the light of all that has been discussed, what should be the Christian response to the relationship with the akonwa tuntum?

\section{A Christian response: The Lesson from the story of Naaman, the Syrian leper (2 Kings 5:1-27)}

On the $3^{\text {rd }}$ of April, 1909, in what could be termed a regnum and sacerdotal controversy, the Commissioner of the Southern Province of Ashanti, C. H. Armitage, in presenting his observations about a resolution by the churches in Ashanti to the Chief Commissioner in Kumasi, wrote:

I would venture to suggest that if they showed a little more tolerance and studied more carefully the Creed of the Ashantis (i.e. not condemning every rite off hand as "vile" or "degrading"), they would meet with more consideration at the hands of the chiefs. Surely it would not be wrong in dealing with an ignorant and superstitious race to infuse into their doctrine a little of the spirit which prompted Elisha to reassure Naaman on his convertion (sic). (2 Kings Chap V verses 17, 18, 19) ${ }^{37}$

That Armitage raises the illustration of Naaman is significant for our context. Naaman was a commander of the army of the king of Aram through whom the Lord had given victory to Aram in several raids or battles, and who suffered from leprosy. An Israeli slave girl who was captured in one of the Aramean raids served in the house of Naaman, and through her Naaman is directed to seek divine intervention through the Prophet Elisha. Elisha directs Naaman to go and dip himself seven times in the river Jordan. Elisha uses the river Jordan as the 'medium for ritual purification' 38 and after the seventh immersion Naaman was completely healed. He then stood before Elisha and declared, 'Now I know that there is no God in all the world except in Israel' ( 2 Kings 5:15b). This declaration demonstrated a complete change of theological orientation. Commenting on this declaration Fritz asserts:

On this occasion he professes Yahweh as the only God on earth, which amounts to a statement of consequent monotheism such as developed only in the exilic and postexilic period. Monotheism is here understood as the worship of Yahweh as the only God to the extent of denying the existence of other gods. ${ }^{39}$

The worship of Yahweh in the Aramean context was, however, to raise a question that had to be resolved. He asked of Elisha:

Please let me, your servant, be given as much earth as a pair of mules can carry, for your servant will never again make burnt offerings and sacrifices to any other god but the Lord. But may the Lord forgive

\footnotetext{
34 Addo Dankwa, The Institution of Chieftaincy in Ghana, 73.

35 Interview on $25^{\text {th }}$ August, 2014, at Sanoma palace.

36 Addo Dankwa, The Institution of Chieftaincy in Ghana, 74.

37 PRAAD - K, ARG./1/30/2/1. A letter from C. H. Armitage, Commissioner of Southern Province of Ashanti to the Chief Commissioner, Kumasi, dated $3^{\text {rd }}$ April, 1909. (PRAAD - Public Records and Archives Administration Department of Ghana).

38 Volkmar Fritz, 1 \& 2 KINGS: A Continental Commentary (Minneapolis: Fortress Press, 2003), 259.

39 Ibid, 260.
} 
your servant for this one thing: When my master enters the temple of Rimmon to bow down and he is leaning on my arm and I bow there also - when I bow down in the temple of Rimmon, may the Lord forgive your servant for this. (2 Kings 5: 17-18)

Fritz presents this problem in two questions: He states, 'These verses subsequently thematise the problem that results for Naaman: how can he stay true to his confession and still fulfil his duty as a state official? How can he be loyal both to the newly found God and to his king who worships other gods? ${ }^{40}$

These questions are significant in the Asante context of the Christian chief and his relationship with the traditional rituals of chieftaincy. How can the Christian chief stay true to his confession of Christ as Lord and still fulfil his duties as state official who is, as such, required to perform certain traditional ritual functions? How can the Asante Christian chief be loyal to the Lord Jesus and still perform the ritual obligations of his office? These are genuine questions that confront the Asante Christian chiefs of today.

The response of Elisha is remarkable and gives insight into resolving the issues. He replied: 'Go in peace' (2 Kings 5:19a). According to Fritz, 'Naaman asks for forgiveness for his conduct, which is neither granted nor precluded by Elisha's response'. ${ }^{41}$ According to Auld, however, Naaman asks for a dispensation in which he would have the opportunity to fulfil his ceremonial duties, and that at 'the very least, Elisha must have been satisfied with the enthusiasm of the new worshipper. ${ }^{42}$ And Jones is of the view that, 'Go in peace' amounts to Elisha's consent to Naaman's request. ${ }^{43}$ Auld further puts forward an argument, but in a question form, thus:

Are this story and the story of Jonah concerned with foreign, pagan Syrians and Assyrians and the possibility or the terms of their conversion to worship of Yahweh? ${ }^{44}$

The answer to this question, according to him, is given right at the beginning of the story of Naaman, that: God had given victory to Aram through him..$^{45}$ The implication is that God was also at work among the Arameans and could be laying down the terms for their conversion which would not involve a complete break with their traditions. The converts would go through the same rituals but with different meanings. This principle was applied in the barbarian conversion of Europe which is implied in a message Pope Gregory sent to Bishop Augustine, a missionary to Britain in AD 597. The message reads:

And since they have a custom of sacrificing many oxen to demons, let some other solemnity be substituted in its place ... They are no longer to sacrifice beasts to the Devil, but they may kill them for food to the praise of God, and give thanks to the Giver of all gifts for the plenty they enjoy. ${ }^{46}$

The same ritual was performed, an animal was to be killed, but the meaning had changed and therefore was no longer the same sacrifice. Asante Christian chiefs do not need to approach the rituals of chieftaincy as a form of worship but as cultural activities.

\section{CONCLUSION}

The examination of the various issues that have arisen from the Christian chief's relationship with the Akonwa tuntum has revealed that they have resulted from the lack of understanding of the meanings behind the traditional rituals. The Akonwa tuntum is not demonic, as perceived by Christians, but instituted for social, historical, educational and political purposes. The Christian chief needs not fear contamination by sitting on the akonwa tuntum with Christ in him, since the contamination of a Christian comes from within and not without. The application of blood to the stools is a means of preserving and not worship of them. The Christian Asante chief should therefore approach the akonwa tuntum as a purely cultural symbol.

\footnotetext{
40 Ibid.

41 Frits, $1 \& 2$ KINGS, 260.

42 A. Graeme Auld, $1 \& 11$ Kings (Louisville: Westminster John Knox Press, 1986), 168.

43 G. H. Jones, $1 \& 2$ Kings, Volume 11 (Grand Rapids: Wm B. Eerdmans Publishing Company, 1984), 420.

44 Auld, 1 \& 11 Kings, 168.

4 Ibid.

46 Bede. Ecclesiastical History of the English People. Translated by Leo Shirley-Price. London: Penguin Group, $1955,92$.
} 


\section{BIBLIOGRAPHY}

Auld, A. Graeme. 1 \& 11 Kings. Louisville: John Knox Press, 1986.

Bede. Ecclesiastical History of the English People. Translated by Leo Shirley-Price. London: Penguin Books, 1955.

Bediako, Kwame. Theology and Identity: The Impact of Culture upon Christian Thought in the Second Century and in Modern Africa. Paternoster: Regnum Books, 1992.

Boadi, J. A. Christianity or Traditional Beliefs and Customs? Accra: U.G.C. Publishing House, 2001.

Bock, Darrell L. Luke: Vol. 1. Grand Rapids: Baker Books, 1994.

Busia, Kofi Abrefa. The position of the chief in the modern political system in Ashanti: A study of the influence of contemporary social changes on Ashanti political institutions. London: OUP, 1951.

Carson, D. A. 'Matthew' in F. E. Gaebelein (ed.). The Expositor's Bible Commentary: Vol. 8. Grand Rapids: The Zondervan Corporation, 1984.

Christaller, J. G. Dictionary of the Asante and Fante Language called Tshi (Twi). Basel: The Basel Evangelical Mis sionary Society, 1933.

Dankwa, Oseadeeyo Addo. The Institution of Chieftaincy in Ghana - The Future. Accra: Gold Type Ltd., 2004. Farley, G. E. 'Circumcision' in Merrill C. Tenney (ed.). Pictorial Encyclopedia of the Bible, Volume 1: A-C. Grand Rapids: The Zondervan Publishing House, 1976.

Fritz, Volkmar. 1 \& 2 Kings: A Continental Commentary. Minneapolis: Fortress Press, 2003.

Kapolyo, Joe. 'Matthew' in Tukumbo Adeyemo (ed.). Africa Bible Commentary. Nairobi: WordAlive Publishers, 2006.

Labi, Kwame Amoah. 'Cross-cultural appropriation of regalia and royal art, and contemporary adaptations in Ghana' in Irene K. Odotei and Albert K. Awedoba (eds.). Chieftaincy in Ghana: Culture, Governance and Development. Accra: Sub-Saharan Publishers, 2006.

Opuni-Frimpong, Kwabena. Indigenous knowledge and Christian missions: Perspectives of Akan leadership forma tion on Christian Leadership Development. Accra: SonLife Press, 2012.

Peterman, Gerald W. (Ed.). Matthew Henry's Commentary for the NIV. London: Marshall Pickering, 1992.

Sarpong, Peter. The Sacred Stools of the Akan. Tema: Ghana Publishing Corporation, 1971.

Wansbrough, Henry. The New Jerusalem Bible. London: Darton, Longman \& Todd Ltd., 1985.

Wassel, Walter W. 'Mark' in F. E. Gaebelein (ed.). The Expositor's Bible Commentary: Vol. 8. Grand Rapids: The Zondervan Corporation, 1984. 